\title{
Description of a new species of the stag beetle genus Auxicerus Waterhouse, 1883 (Coleoptera: Scarabaeoidea: Lucanidae)
}

\author{
Robert PERGER ${ }^{1, *}$, Paschoal Coelho GROSSI ${ }^{2}$ \& Fernando GUERRA ${ }^{3}$ \\ ${ }^{1,3}$ Colección Boliviana de Fauna, Casilla 10077, Correo Central, La Paz, Bolivia. \\ ${ }^{2}$ Universidade Federal Rural de Pernambuco, Departamento de Agronomia/Fitossanidade, \\ Laboratório de Taxonomia de Insetos, Rua Manoel Medeiros, s/n, \\ Dois Irmãos 52171-900 - Recife, PE, Brazil. \\ ${ }^{3}$ Instituto de Ecología, Universidad Mayor de San Andrés, Casilla 10077, \\ Correo Central, La Paz, Bolivia. \\ *Corresponding author: robertperger@hotmail.com \\ ${ }^{2}$ Email: paschoal.grossi@gmail.com \\ ${ }^{3}$ Email: ferguerrafideo@yahoo.com \\ ${ }^{1}$ urn:Isid:zoobank.org:author:1019F079-5C55-4467-80BE-DBB75A50F10F \\ ${ }^{2}$ urn:lsid:zoobank.org:author:5347A9A1-F9DD-44E8-ABB8-2542E8EDF1FB \\ ${ }^{3}$ urn:1sid:zoobank.org:author:35C6845C-9FC8-4541-B329-82FC44FE0DF7
}

\begin{abstract}
A new species of the Andean stag beetle genus Auxicerus Waterhouse, 1883 is described from the humid Tucuman-Bolivian forest in the southern Bolivian Andes. Auxicerus magnipunctatus sp. nov. is distinguished from all congeners by the distinctly larger punctures of the mesosternum; antennomeres 2-6 subquadrate, last two joints of club wider than long; lamellae not widely separated; posterior end of ocular canthus rounded and anterior edge of canthus moderately developed into an obtuse triangle. Auxicerus magnipunctatus sp. nov. is possibly endemic to the Tucuman-Bolivian forest. Along with the presence of other endemic beetle species with tropical congeners, the discovery of A. magnipunctatus sp. nov. supports the idea that the persistence of rather tropical taxa in the subtropical realm is fostered by increased humidity at orographic rain barriers and climatic stability in the Tucuman-Bolivian forest.
\end{abstract}

Keywords. Andes, Bolivia, Neotropical, South America, Tucuman-Bolivian forest.

Perger R., Grossi P.C. \& Guerra F. 2016. Description of a new species of the stag beetle genus Auxicerus Waterhouse, 1883 (Coleoptera: Scarabaeoidea: Lucanidae). European Journal of Taxonomy 302: 1-10. https://doi. org/10.5852/ejt.2016.302

\section{Introduction}

The northern tropical Andes is an important center of diversity and endemism, a pattern that has been attributed to the fact that the mountains promote isolation and speciation (by high topographic complexity and habitat heterogeneity) and favor long-term persistence of lineages (by harboring more climatically stable refugia versus the lowlands) (review by Hoorn et al. 2010; Antonelli \& Sanmartín 
2011). However, because of a change in orientation of the mountain ranges at the Bolivian orocline and local topographic features, the Andes in southern Bolivia and northern Argentina are distinguished by a pronounced seasonality, less annual precipitation and a lower biodiversity than the northern tropical Andes (Ibisch et al. 2003; Churchill \& Lozano 2009). Corresponding with the general decrease in biodiversity, several scarabaeoid genera, including Dynastes Kirby, 1825, Scortizus Westwood, 1834 and Cantharolethrus Thomson, 1862, meet their southern distributional limit at the Bolivian orocline (see Paulsen 2010 for approximate distributional maps of the lucanid taxa).

The stag beetle genus Auxicerus Waterhouse, 1883 includes three species, A. platyceps (Waterhouse, 1883), A. multicolor (Boileau, 1897) and A. aethiops (Jakowleff, 1900), exclusively found in the tropical Andes of Peru and Bolivia. Auxicerus platyceps and A. multicolor have been found at the southern limit of the humid Bolivian Andes forest in Samaipata and Los Volcanes (Paulsen in litt.; this study), suggesting that the species of this genus, as with the other scarabaeoid taxa mentioned earlier, are not able to persist in the subtropical southern Bolivian Andes.

However, during a biodiversity survey in the Sub-Andean humid Tucuman-Bolivian forest (Navarro \& Ferreira 2011) in the southern Bolivian Andes, $600 \mathrm{~km}$ south of the southernmost record of Auxicerus, a single, minor male of this genus was discovered. This specimen is distinguished by several unique character states that cannot be attributed to any of the previously described species of Auxicerus. Thus, the purpose of this paper is to describe this new species of Auxicerus.

\section{Material \& methods}

Sampling was conducted with a beating sheet in midstorey vegetation along a mountain slope at an elevation between 500 and $2000 \mathrm{~m}$ at the border between Bolivia and Argentina, close to the southeastern area of Tariquía National Reserve (Arce Province, Tarija Department) in the southern Bolivian Andes (Fig. 1). The forest in this area is considered a sub-Andean humid Tucuman-Bolivian forest (Navarro \&


Fig. 1. A. Bolivian records of Auxicerus platyceps Waterhouse, 1883 (open circle, solid rectangle); Auxicerus multicolor (Boileau, 1897) (open rectangle, solid rectangle) and Auxicerus magnipunctatus sp. nov. (solid circle). Localities: (1) Consata, (2) Caranavi, (3) Coroico, Chairo, (4) Los Volcanes and (5) Emborozu. B. Habitat of Auxicerus magnipunctatus sp. nov. in humid Tucuman-Bolivian forest. 
Ferreira 2011) and potentially receives an annual rainfall of up to $3000 \mathrm{~mm}$ (Bookhagen \& Strecker 2008).

The collected material was deposited in the Colección Boliviana de Fauna (La Paz, Bolivia) (CBF). Morphological characteristics were examined with a stereo microscope and measurements of the body length (BL) (length between tip of mandibles and posterior end of elytra) and body width (BW) (width at humeri) were taken with a digital caliper. Photographs were taken with the Visionary Digital Passport II Imaging system at the Zoological Museum, University of Hamburg, Germany.

We examined comparative material in the collections of the Natural History Museum London (BMNH), the Everardo and Paschoal Grossi Private Collection (Nova Friburgo, RJ, Brazil) (EPGC), the Alain Galant Private Collection (AGC), the Luca Bartolozzi Private Collection (LBC) and the Zoological Institute of the Russian Academy of Sciences, St. Petersburg (ZIRAS).

\title{
Results
}

\section{Taxonomy}

\author{
Class Hexapoda Blainville, 1816 \\ Order Coleoptera Linnaeus, 1758 \\ Suborder Polyphaga Emery,1886 \\ Superfamily Scarabaeoidea Latreille, 1802 \\ Family Lucanidae Latreille, 1804 \\ Subfamily Lucaninae Latreille, 1804 \\ Genus Auxicerus Waterhouse, 1883
}

Auxicerus Waterhouse, 1883: 387.

\section{Type species}

Auxicerus platyceps Waterhouse, 1883 (by monotypy).

\section{Diagnosis}

Male head large, transverse, anterior edge of ocular canthus triangular, projecting beyond anterior edge of head and antennal base. Mandibles horizontal in lateral view, sickle-shaped, basally with three moderately developed teeth, apical half without teeth, acuminate. Mentum strongly transverse, sides rounded, apex widely emarginated. Pronotum transverse, posterior angles obliquely emarginated. Mesosternum with U-shaped concavity. Procoxae only slightly separated, the prosternum not produced into a process posteriorly.

\section{Auxicerus platyceps Waterhouse, 1883}

Fig. 2A-B

Auxicerus platyceps Waterhouse, 1883: 387.

Auxicerus platyceps - Jakowlew 1900: 38. - Blackwelder 1944: 195. — Weinreich 1963: 202. — Benesh 1960: 51. — Maes 1992: 64. — Mizunuma \& Nagai 1994: 279.

\section{Material examined}

\section{Holotype}

PERU: ô, 1917 [no other data], BL 13 mm (BMNH). 


\section{Other material}

PERU: 1 đૈ, Yanachaga-Chemillen National Park, Puerto Bermudez, 2200 m a.s.l., Feb. 2009 (AGC); $1 \partial^{\lambda}$, Chanchamayo (AGC).

BOLIVIA: Santa Cruz Department: $2 \hat{\jmath} \widehat{\partial}$, BL 10.15 and $14.9 \mathrm{~mm}$, Amboro National Park, Los Volcanes, 1000 m a.s.1., $18^{\circ} 06^{\prime}$ S, $63^{\circ} 36^{\prime}$ W, 20 Nov. -12 Dec. 2004, MV light sheet on stream beach, M.V.L.
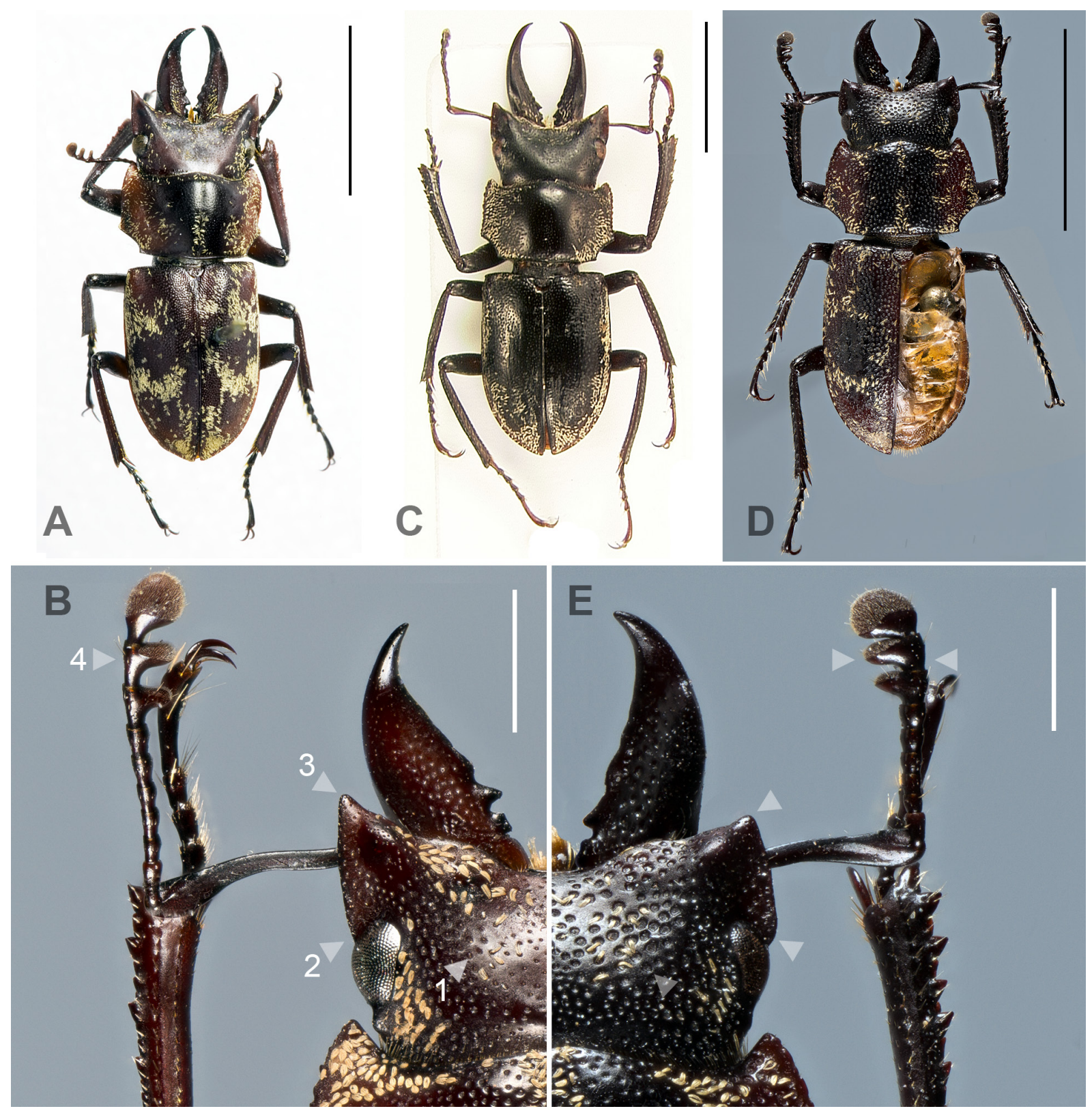

Fig. 2. A-B. Auxicerus platyceps Waterhouse, 1883. A. Holotype, ð̊, BL 13 mm (BMNH). B. Head, ðૈ, BL $11 \mathrm{~mm}$, Bolivia, Consata (EPCG). - C. Auxicerus aethiops Jakowleff, 1900, holotype, ô, BL $16 \mathrm{~mm}$, Bolivia (ZIRAS). - D-E. Auxicerus magnipunctatus sp. nov., holotype, ô, BL $10.7 \mathrm{~mm}$ (CBF). D. Dorsal habitus. E. Head. Diagnostic characters indicated by arrows: (1) ocellate punctures on mesosternum, (2) posterior end of ocular canthus, (3) anterior edge of ocular canthus and (4) antennal lamellae. Scale bars: A, C-D $=5 \mathrm{~mm}$; B, E $=2.5 \mathrm{~mm}$. 
Barclay and H. Mendel leg. (EPGC); 1 §, 2 우, BL 12.5 and $9.1 \mathrm{~mm}$, Los Volcanes, $4 \mathrm{~km} \mathrm{~N}$ of Bermejo

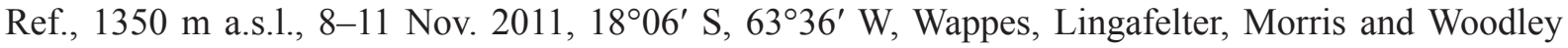
leg. (EPGC). — La Paz Department: 1 ð, BL 11 mm, Consata, 2000 m a.s.l., Sep. 2008 (EPGC); 1 ○, BL 12.0 mm, Nor Yungas, Coroico, 16²12' S, 6748' W, 1200 m a.s.1., 18-28 Nov. 2008 (EPCG).

\section{Geographical distribution}

Peru (Canchamayo); Bolivia (La Paz, Santa Cruz).

Auxicerus multicolor (Boileau, 1897)

Calodaemon multicolor Boileau, 1897: 248.

Calodaemon multicolor - Boileau 1898a: 119.

Auxicerus multicolor - Boileau 1898b: 418. — Blackwelder 1944: 195. — Didier \& Séguy 1953: 28. Weinreich 1963: 204. — Benesh 1960: 51. — Maes 1992: 64. — Bomans 1994: 488. — Mizunuma \& Nagai 1994: 279.

\section{Material examined}

BOLIVIA: Santa Cruz Department: 1 ภ, BL 13.5 mm, Amboro National Park, Los Volcanes, $1000 \mathrm{~m}$ a.s.1., $18^{\circ} 06^{\prime} \mathrm{S}, 63^{\circ} 36^{\prime} \mathrm{W}$, MV light sheet on stream beach, 20 Nov.-12 Dec. 2004, M.V.L. Barclay and H. Mendel leg. (ex coll. BMNH) (LBC). — La Paz Department: 2 ふぇ, BL 11.2 and $13.1 \mathrm{~mm}$, Nor Yungas, Cotapata Park, near Chairo, 16 ${ }^{\circ} 12,01^{\prime}$ S, 67048,31' W, 1150 m a.s.1., 19 Jan. 2009 (EPCG); $3 \widehat{\jmath} \hat{\mathrm{o}}$, BL 14.0, 14.1 and $15.5 \mathrm{~mm}$, Nor Yungas, road between Coroico and Caranavi, 1000-1800 m a.s.l., Nov. 2009, local collector (EPCG); 1 §̂, BL 18 mm, Caranavi, 1500 m a.s.1., Nov.-Dec. 1990, local collectors (ex coll. H.E. Bomans) (LBC).

\section{Remarks}

The taxonomy of A. platyceps and A. multicolor, both sympatric in the Yungas forest of the La Paz and Santa Cruz departments, is complicated by their close resemblance and the variability of several characteristics used to separate both species (see Weinreich 1963), such as color and the distribution of scales. Additionally, as in several other species of this family, inter-specific comparison is complicated by the allometry of several structures of the head. Nevertheless, these species can be separated by the following characteristics of the legs and the ventral surface: proximal half of femora and distal half of tibiae brownish in A. platyceps (light red to red in A. multicolor); head with gena more distinctly and strongly punctate in A. platyceps; gular suture posteriorly more distinct in A. multicolor, and weakly marked in $A$. platyceps; in $A$. platyceps anterior angles of prementum more prominent and anterior pronotal angles more obtuse than in A. multicolor; prosternum flattened and with parallel sides in A. platyceps, and convex with rounded sides in A. multicolor; mesosternum more triangular in A. multicolor; abdominal sternites more strongly and densely punctate in A. platyceps.

\section{Geographical distribution}

Bolivia (La Paz, Santa Cruz).

Auxicerus aethiops Jakowleff, 1900

Auxicerus aethiops Jakowleff 1900: 38.

\section{Material examined}

Holotype

BOLIVIA: $\widehat{\partial}$ [no other data], BL 16 mm (ZIRAS). 


\title{
Remarks
}

In his revision of the genus Auxicerus, Weinreich (1963) did not examine the types of A. platyceps and $A$. aethiops and considered A. aethiops quite similar to A. platyceps. However, the holotype of A. aethiops has comparatively longer mandibles in combination with a narrow head and a less acute ocular canthus and lacks the longitudinal depressions on the pronotal disc (compare Fig. 2A-B). Additionally, in A. aethiops the elytral surface is entirely shiny and uniformly punctate (in A. platyceps the elytral surface is shiny only along the suture, elsewhere opaque; and the punctures are larger near the suture). Thus, A. aethiops is considered here as a valid species.

\section{Geographical distribution}

Bolivia.

\author{
Auxicerus magnipunctatus sp. nov. \\ urn:Isid:zoobank.org:act:5BB0BCE7-A060-45E2-AD54-FD2882697754
}

Fig. 2D-E

\section{Differential diagnosis}

Auxicerus magnipunctatus sp. nov. is distinguished from all congeners by the posterior end of the ocular canthus being rounded and the anterior edge of the canthus moderately developed into an obtuse tooth; distance between apex of teeth as wide as distance between outer eye margins (Fig. 2E). Antennomeres 2-6 subquadrate, last two joints of club wider than long; lamellae not widely separated from each other (Fig. 2E). Punctures of mesosternum larger; mesosternum concavity weak.

\section{Etymology}

The species epithet is derived from the Latin 'magna' (large) and the Latin 'punctatus' (punctures), in reference to the large punctures all over the body.

\section{Material examined}

\section{Holotype}

BOLIVIA: Ō labeled: “Bolivia / Tarija department / Arce province / S22 ${ }^{\circ} 13^{\prime} 20 \mathrm{~W} 64^{\circ} 36^{\prime} 03$ / $1049 \mathrm{~m}$ a.s.1. / mountain slope / Tucuman-Bolivian subhumid forest / midstorey vegetation / beating tray / 15-I2012 / R. Perger and F. Guerra leg." (CBF).

\section{Description}

Body. BL $10.7 \mathrm{~mm}$, BW $3.6 \mathrm{~mm}$. Body compressed, dorsal surface reddish-black to brownish-black, almost glabrous with scattered scale-like setae on mandibles, head, pronotum and elytra; densely and strongly punctate. Venter brownish-black.

HEAD (Fig. 2E). Shape transverse, with large ocellate punctures, on disc and near eyes with a scale-like seta in each puncture; ocular canthus posteriorly intruding over anterior $1 / 4$ of eye, posterior canthus rounded; anterior edge of canthus moderately developed into obtuse triangle, distance between apices of canthi as wide as distance between outer eye margins; temporal process weakly pronounced as a tiny tubercle. Mandibles apparently symmetric, as long as head length, and sickle-shaped; inner dorsal surface with large punctures, near base with scattered scale-like setae; basal half with dorso-lateral carina, inner base with 3 teeth, 2 distinct at base, the apical tooth near obsolete; apex acuminate, and slightly upturned. 
Antennae. With scape as long as head midline length, flexuous; 2-6 antennomeres, subquadrate, short; pedicel distinctly longer than 3-6 antennomeres alone; club with lamellae not widely separated; last two joints of club wider than long, short, apical half of lamella pubescent.

Pronotum. Shape subtrapezoidal, lateral borders crenulated; sides lined by scale-like setae, especially near lateral and posterior angles; pronotal disc dark brown, shiny, moderately punctate, punctures large, decreasing in size to sides; longitudinal furrow, anteriorly and posteriorly, with scale-like setae interrupted at middle; sides reddish-black, weakly sinuous just before posterior emargination; anterior angles acute, projecting forward; lateral angles near straight; posterior angles distinctly sharp.

ELYTRA. Surface shiny, almost completely punctate, except for a rounded, opaque medio-lateral area surrounded by scale-like setae; punctures large, becoming coalescent near humeri, opaque area and elytral apex; borders except suture with similar setae, and near epipleuron setae more scattered. Scutellum obtusely rounded posteriorly, with small setose punctures mainly on disc.

LEGS. Surface of each tibia covered with a longitudinal row of erect, white setae; outer apical border of all tibiae produced into obtuse tooth; outer apical half of protibia with four larger teeth, between them smaller, rounded reddish-black teeth; mesotibia possesses one weakly developed outer tooth.

A comparison of the male genitalia is not included in the description because the holotype is too fragile to be rehydrated and dissected after its storage in ethanol and subsequent drying.

\section{Comparisons}

The other species of Auxicerus differ from A. magnipunctatus sp. nov. as follows: punctures on head finer; second to sixth antennomeres slender, about twice as long as wide; lamellae widely separated. All examined specimens of $A$. platyceps, including males smaller than $A$. magnipunctatus sp. nov., have a distinctly pronounced acute anterior edge of the ocular canthus (moderately developed into an obtuse tooth in A. magnipunctatus sp. nov.). Assuming that these characteristics vary in A. aethiops in the same range as in A. platyceps, it is likely that smaller individuals of $A$. aethiops also have a more prominently developed anterior edge of the ocular canthus than A. magnipunctatus sp. nov.

\section{Geographical distribution}

This new species is currently known only from the type locality (Fig. 1). Despite further efforts by RP and FG to collect more individuals in other locations of the Tucuman-Bolivian forest in the last four years, no other specimens have been found. Nevertheless, A. magnipunctatus sp. nov. likely occurs as well in a similar habitat (Sub-Andean humid Tucuman-Bolivian forest) along the eastern slope of Chuquisaca and Tarija Departments (Bolivia) to the Jujuy, Salta, Tucuman and Catamarca departments (Argentina).

\section{Key to the males of Auxicerus Waterhouse, 1883}

1. Antennal lamellae distinctly separated, distance between lamellae larger than width of first lamella

- Antennal lamellae not distinctly separated, distance between lamellae considerably smaller than width of first lamella Auxicerus magnipunctatus sp. nov.

2. Proximal half of femora and distal half of tibiae light red to red ....... multicolor (Boileau, 1897)

- Proximal half of femora and distal half of tibiae brownish ..................................

3. Elytral surface entirely shiny and uniformly punctate ................. A. aethiops Jakowleff, 1900

- Elytral surface shiny only along suture, elsewhere opaque; punctures larger near suture A. platyceps Waterhouse, 1883 


\section{Discussion}

Given the probability that a morphological difference can be an aberration or the result of intra-specific variability, it is recommended to include more individuals in a species description (Mąkol \& Gabryś 2005). Nevertheless, we believe that the single specimen of the new taxon is clearly distinguishable from its congeners on the basis of a combination of distinct morphological characteristics. Moreover, it is uncertain when additional individuals will be collected. Furthermore, the species is very likely endemic to the spatially-restricted and minimally-protected Tucuman-Bolivian forest ecoregion (see Perger \& Guerra 2013 for a short review) and would probably require particular attention in terms of conservation planning.

Besides A. magnipunctatus sp. nov., recent surveys in the study area revealed additional undescribed species belonging to beetle genera that were previously suggested to be endemic to the northern tropical Andes (Pseudoxycheila Guérin-Méneville, 1839, Carabidae, see Perger \& Guerra 2012; and Oryctophileurus Kolbe,1910, Scarabaeidae, see Perger \& Grossi 2013) or to other moist forests in Central and South America (Gymnognathus Schönherr, 1826, Anthribidae, see Perger \& Guerra 2016). These findings suggest that the presence of rather tropical taxa in the subtropical realm is fostered by increased humidity at orographic rain barriers and the climatic stability in the Tucuman-Bolivian forest. The climatic stability based on orographic rain barriers may also have lowered extinction rates of rather tropical taxa during periods of drastic climate change, like the Pleistocene cycles, which is also supported by the presence of several endemic plant species (Brown et al. 2001) and birds (Fjeldså et al. 1999) with tropical congeners. The growing number of endemic species newly described from the Tucuman-Bolivian forest calls for a re-assessment of the conservation status of this ecoregion.

\section{Acknowledgments}

Max Barclay (BMNH), Dr. Matt Paulsen (University of Nebraska State Museum, Lincoln, USA), Dr. Luca Bartolozzi (University of Florence, Italy) and Alain Galant are thanked for providing photographs of specimens of Auxicerus, and Kai Schütte (University of Hamburg, Germany) for helping with the photographs of $A$. magnipunctatus sp. nov. We are also grateful to Gavin Broad (BMNH) and an anonymous reviewer for commenting on an earlier draft of this manuscript. PCG received financial support from Conselho Nacional de Ciência e Tecnologia, process number 449366/2014-6.

\section{References}

Antonelli A. \& Sanmartín I. 2011. Why are there so many plant species in the Neotropics? Taxon 60: 403-414.

Benesh B. 1960. Coleopterorum Catalogus Supplementa, Pars 8. Lucanidea. W. Junk, The Hague, Netherlands.

Blackwelder R.E. 1944. Checklist of the coleopterous insects of Mexico, Central America, the West Indies, and South America, Part 2. Bulletin of the United States National Museum 185: 189-341.

Boileau H. 1897. Description d'un lucanide nouveau. Le Naturaliste 19: 247-248.

Boileau H. 1898a. Description d'un lucanide nouveau. Le Naturaliste 20: 119-120.

Boileau H. 1898b. Note sur le "Catalogue des Lucanides" de M. Carl Felsche. Annales de la Société entomologique de France 67 (3): 401-437.

Bomans H.E. 1994. Signalisation de quelques espèces intéressantes de Lucanidae (86iéme contribution à l'étude des coléoptères lucanides). Lambillionea 94 (4): 487-497. 
Bookhagen B. \& Strecker M.R. 2008. Orographic barriers, high-resolution TRMM rainfall, and relief variations along the eastern Andes. Geophysical Research Letters 35: 1-6. https://doi. org/10.1029/2007GL032011

Brown A.D., Grau H.R., Malizia L.R. \& Grau A. 2001. Argentina. In: Kappelle M. \& Brown A. (eds) Bosques Nublados del Neotrópico: 621-659. Inbio, San José, Costa Rica.

Churchill S.P. \& Lozano R. 2009. Bryophytes of the Tucumán-Bolivian montane forest. Bryophyta Diversity and Evolution 30: 19-42. https://doi.org/10.11646/bde.30.1.6

Didier R. \& Séguy E. 1953. Catalogue illustré des Lucanides du Globe. Texte. Encyclopédie Entomologique 27 (A): 1-223. Lechevalier, Paris.

Fjeldså J., Lambin E. \& Mertens B. 1999. Correlation between endemism and local ecoclimatic stability documented by comparing Andean bird distributions and remotely sensed land surface data. Ecography 22: $63-78$.

Hoorn C., Wesselingh F., Steege H.T., Mora A., Sevink J., Sanmartin I., Sanchez-Meseguer A., Anderson C.L., Figueiredo J., Jaramillo C., Riff D., Negri F.R., Hooghiemstra H., Lundberg J.G., Stadler T., Sarkinen T. \& Antonelli A. 2010. Amazonia through time: Andean uplift, climate change, landscape evolution and biodiversity. Science 330: 927-931. https://doi.org/10.1126/science.1194585

Ibisch P.L., Gerkmann B., Kreft S., Beck S.G., Herzog S.K., Köhler J., Müller R., Reichle S. \& Vásquez R. 2003. Consideraciones comparativas de patrones interecoregionales de diversidad de especies y de endemismo. In: Ibisch P.L. \& Mérida G. (eds) Biodiversidad: la Riqueza de Bolivia. Estado de Conocimiento y Conservación: 148-161. Ministerio de Desarrollo Sostenible, Editorial Fundación Amigos de la Naturaleza (FAN), Santa Cruz, Bolivia.

Jakowleff B.E. 1900. Description de quelques nouvelles espèces de la famille des lucanides. Horae Societatis Entomologicae Rossicae 34: 631-642.

Maes J.M. 1992. Lista de los Lucanidae (Coleoptera) del Mundo. Revista Nicaraguense de Entomologia 22B: $61-121$.

Mąkol J. \& Gabryś G. 2005. Intuition or fixed criteria - about standards in species description. Genus 16: 503-511.

Mizunuma T. \& Nagai S. 1994. The lucanid beetles of the World. In: Fujita H. (ed.) Mushi-Sha's Iconographic Series of Insects. Vol. 1: 279. Mushi-sha, Tokyo.

Navarro G. \& Ferreira W. 2011. Mapa de Sistemas Ecológicos de Bolivia, escala 1:250 000. Edición CD-ROM. RUMBOL SRL-The Nature Conservancy (TNC), Bolivia.

Paulsen M.J. 2010. Annotated checklist of the New World Lucanidae, version 3.0. Available from http:// www-museum.unl.edu/research/entomology/Guide/Scarabaeoidea/Lucanidae/Lucanidae-Catalog/ LucanidaeC.htm [accessed 1 May 2015].

Perger R. \& Grossi P. 2013. Revision of the rhinoceros beetle genus Oryctophileurus Kolbe with description of a new species, the male of $O$. varicosus Prell, and notes on biogeography (Scarabaeoidea, Dynastinae, Phileurini). ZooKeys 346: 1-16. https://doi.org/10.3897/zookeys.346.6114

Perger R. \& Guerra F. 2012. Two new tiger beetle (Coleoptera, Carabidae, Cicindelitae) species from the Tucuman-Bolivian forest in the National Tariquía Reserve, Bolivia. Zootaxa 3434: 49-58.

Perger R. \& Guerra F. 2013. Longhorn beetles (Coleoptera: Cerambycidae) of the Tucuman-Bolivian forest in the Tariquía Flora and Fauna National Reserve, southern Bolivian Andes, with notes on ecoregion endemism and conservation. The Pan-Pacific Entomologist 89 (4): 209-221. https://doi. org/10.3956/2013-19.1 
Perger R. \& Guerra F. 2016. The description of a new calyptrate fly mimicking species of the fungus weevil genus Gymnognathus Schönherr, 1826 from the southern Bolivian Andes (Coleoptera: Anthribidae: Anthribinae). Zootaxa 4084 (2): 277-284. https://doi.org/10.11646/zootaxa.4084.2.7

Waterhouse C.O. 1883. Notice of a new genus and species of Lucanoid Coleoptera. The Annals and Magazine of Natural History 5 (12): 387-388. Available from http://biodiversitylibrary.org/ page/16006755 [accessed 6 Feb. 2017]

Weinreich E. 1963. Revision südamerikanischer Lucanidae (Ins. Col.). III. Die Gattungen Pholidotus, Aegognathus, Macrocrates, Auxicerus und Ergänzungen zu Metadorcus, Scortizus, Beneshius und Sclerostomus. Senckenbergiana Biologica 44 (3): 183-212.

Manuscript received: 30 March 2016

Manuscript accepted: 7 July 2016

Published on: 21 March 2017

Topic editor: Gavin Broad

Desk editor: Kristiaan Hoedemakers

Printed versions of all papers are also deposited in the libraries of the institutes that are members of the EJT consortium: Muséum national d'Histoire naturelle, Paris, France; Botanic Garden Meise, Belgium; Royal Museum for Central Africa, Tervuren, Belgium; Natural History Museum, London, United Kingdom; Royal Belgian Institute of Natural Sciences, Brussels, Belgium; Natural History Museum of Denmark, Copenhagen, Denmark; Naturalis Biodiversity Center, Leiden, the Netherlands. 